\title{
Ordynacja wyborcza dla jednego posła Wybory deputowanego do parlamentu wloskiego w Wolnym Państwie Fiume
}

\section{Uwagi wstępne}

W okresie od listopada 1918 r. do stycznia 1924 r. rejon miasta Fiume (dla Chorwatów - Rijeki) nie należał ani do Włoch, ani do Jugosławii. Na arenie międzynarodowej oba wymienione państwa toczyły spór o przynależność regionu, na miejscu zaś włoscy mieszkańcy próbowali sami zdecydować o przyszłości miasta. Jednym z elementów starań o przyłączenie Fiume do Italii były przeprowadzone $\mathrm{w}$ mieście wybory posła do włoskiego parlamentu, które miały podkreślić związek spornego terytorium z Królestwem Włoch. Odbyły się one na podstawie ordynacji uchwalonej w październiku 1919 r. Był to akt stworzony dla określenia reguł głosowania i kandydowania przy wyłanianiu tylko jednego deputowanego; choćby dlatego warto przyjrzeć się tej szczególnej ustawie wyborczej.

Opracowanie rozpoczynamy od przedstawienia najważniejszych wydarzeń w regionie Fiume w latach 1918 - 1924, czyli w okresie, gdy sporny obszar nie należał ani do Włoch, ani do Królestwa Serbów Chorwatów i Słoweńców. Prezentujemy też podstawowe informacje o ustroju wolnego miasta w ostatnich miesiącach 1919 r., czyli w okresie, w którym doszło do uchwalenia ustawy wyborczej będącej przedmiotem artykułu.

Zwięźle przedstawiamy także obowiązujące we Fiume zasady wyłaniana członków Rady Narodowej, a także włoskie prawo określające sposób wybierania 
członków Izby Deputowanych. Przywołanie obu systemów wyborczych uznajemy za celowe, bowiem przyjęte $\mathrm{w}$ wolnym mieście zasady wybierania deputowanego warto porównać z prawną regulacją wyboru włoskich deputowanych, a także z zasadami wyłaniania członków lokalnego organu przedstawicielskiego. Dowiemy się wówczas, czy autorzy ordynacji październikowej wzorowali się na tych rozwiązaniach, czy też — dla wyboru jednego posła — stworzyli ordynację oryginalną.

\section{Zarys dziejów niepodległego miasta Fiume}

Ustrój Fiume w okresie pomiędzy październikiem 1918 r. a sierpniem 1920 r. przedstawiliśmy w innej publikacji ${ }^{1}$, tu przypomnieć należy jedynie kilka najważniejszych faktów.

Od 1867 r. jako tzw. Corpus separatum miasto cieszyło się autonomią w ramach Królestwa Węgier. Jeszcze przed końcem I wojny światowej rozpoczęła się rywalizacja Włochów z Chorwatami o prawa do Rijeki; 29 października 1918 r. chorwacki parlament ogłosił jej włączenie do tworzącego się państwa Słowian południowych, a dzień później włoscy mieszkańcy Fiume powołali Radę Narodową (Consiglio Nazionale), która przejęła zarządzanie miastem. W dniu 4 listopada 1918 r. na miejsce przybyły siły włoskie — oddziały grenadierów wspierane przez dwa okręty, a po nich jednostki wojskowe mocarstw ententy (angielskie, amerykańskie i francuskie), które działały jako siły pokojowe. Władze włoskie nie były gotowe do rozwiązań siłowych, zatem walka o przynależność regionu toczyła się na arenie dyplomatycznej. Doprowadziła ona do kompromisowego traktatu w Rapallo z 12 listopada 1920 r., na mocy którego miało powstać Wolne Państwo Fiume (Stato Libero di Fiume).

Wydarzenia w mieście toczyły się jednak niezależnie od ustaleń dyplomatów. W sierpniu 1919 r. komisja reprezentująca sojusznicze mocarstwa zmusiła oddziały włoskie do opuszczenia Fiume. Już 12 września na czele tych samych, zbuntowanych, jednostek stanął poeta i dramaturg Gabriele d'Annunzio. Tego samego dnia wspierani przez ochotników grenadierzy zajęli Fiume, zmuszając do wycofania się wojska sojuszniczego. G. d'Annunzio, zwany vate (czyli wieszcz), przejął władzę dyktatorską jako Comandante della Cittá di Fiume. Wciąż ostrożne władze Włoch nie spełniły najważniejszego jego postulatu - nie włączono Fiume do Królestwa. Dlatego 12 sierpnia 1920 r. d’Annunzio zdecydował się na

${ }^{1}$ M. Rakowski: Niepodległe miasto na pograniczu włosko-jugostowiańskim - ustrój Fiume przed wydaniem Karty Kwarneru. W: Pogranicza $w$ historii prawa i myśli polityczno-prawnej. Red. D. Szpoper, P. Dąbrowski. Gdańsk—Olsztyn 2017, s. 540—549. 
proklamowanie powstania niepodległego państwa: Włoskiej Regencji Kwarneru, której ustawa zasadnicza (Karta Kwarneru) została ogłoszona już 30 sierpnia. Państewko vate przetrwało jedynie do końca roku, a jego istnienie zakończyła interwencja sił włoskich (Natale di Sangue - krwawe Święta). Otworzyła ona drogę do realizacji postanowień traktatu z Rapallo, czyli powstania Wolnego Państwa Fiume, które istniało jedynie do 1924 r., gdy sporny obszar został włączony do Włoch².

Ustrój wolnego miasta został uregulowany w tymczasowej ustawie zasadniczej Fiume, jaką był dekret o zasadach funkcjonowania Consiglio Nazionale Italiano di Fiume ${ }^{3}$. W preambule tego aktu ogłoszono, że miasto, port i dystrykt Fiume stanowią niezależne państwo (Stato independente), jednocześnie jednak zadeklarowano wolę zjednoczenia z Italią. Najwyższą władzą Fiume i reprezentacją jego mieszkańców miała być Rada Narodowa (Consiglio Nazionale), która $\mathrm{z}$ jednej strony była lokalnym parlamentem, a z drugiej przejęła uprawnienia rządu węgierskiego wobec władz municypalnych (art. 1-19 przywołanego dekretu). Organem wykonawczym, swego rodzaju rządem Fiume, miał być Komitet Wykonawczy (Comitato direttivo) składający się z 21 delegatów, z których część kierowała powierzonymi im resortami (art. 20-33) ${ }^{4}$.

W dekrecie nie określono zasad wyboru członków Rady Narodowej (która już istniała $\mathrm{w}$ dniu uchwalenia aktu). Zapewne jego autorzy zakładali, że do aneksji Włoch dojdzie tak szybko, że nie będzie konieczne przeprowadzanie wyborów do Rady. Gdy okazało się, że spór o przyszłość miasta przedłuża się, przyjęto, że do takich wyborów stosować należy przedwojenne węgierskie przepisy określające zasady wyłaniania Reprezentacji Fiume (o czym niżej). Nowelizacja dekretu styczniowego byłaby utrudniona, bowiem twórcy tego aktu nie przewidzieli również możliwości zmiany jego postanowień ${ }^{5}$.

${ }^{2}$ Ibidem; zob. też: H. Batowski: Rozpad Austro-Węgier 1914-1918. (Sprawy narodowościowe i działania dyplomatyczne). Kraków 1982, s. 18, 39, 126-127, 245, 258-260; G. Benedetti: La pace di Fiume. Dalla conferenza di Parigi al trattato di Roma. Bologna 1924, s. 7-71; E. Cavigiia: Il conflitto di Fiume. [Milano] 1948, s. 7-118, 185-188; A. Depoli: Fiume. Una storia meravigliosa. Padova 1969, s. 85-120; Droit et devoirs de l'Italie. [Roma 1919], s. 46-47; S. Gigante: Storia del Comune di Fiume. Firenze 1928, s. 71-77, 174238; G. Giurati: Con D'Annunzio e Millo in difesa dell'Adriatico. Firenze 1954, s. 8, 44-50, 62-64, 114-116, E. De Michelis: Guida a D'Annunzio. Torino 1988, s. 444-458; D. Patafta: Promjene u nacionalnoj strukturi stanovništva grada Rijeke od 1918. do 1924. godine. „Časopis za suvremenu povijest” 2004, č. 2 (vol. 36), s. 683-700; S. Sierpowski: Faszyzm we Wloszech 1919-1926. Wrocław-Warszawa-Kraków-Gdańsk 1973, s. 94-95.

${ }^{3}$ Decreto 22 gennaio 1918, n. 407, concernente le norme per il funzionamento del Consiglio Nazionale Italiano di Fiume. In: Ministero della Giustizia e degli Affari di Culto. Comitato Tecnico per La Legislazione Relativa all'Unificazione del Diritto nelle Nuove Provicie: Legislazione di Fiume. Raccolta e coordinata da D. Barone, G.P. Gaetano. Vol. 1: Provvedimenti legislativi dei governi provvisori. Roma 1926, s. 37-43.

${ }^{4}$ M. Rakowski: Niepodlegte..., s. 542-544.

${ }^{5}$ Ibidem. 
Po przejęciu dyktatorskiej władzy przez d'Annunzia dekret styczniowy formalnie nadal obowiązywał, choć władzą wykonawczą stał się komendant z utworzonym przez siebie gabinetem (Gabinetto di Comando). W dniu 26 października 1919 r. odbyły się wybory do Consiglio Municipale della Cittá, przeprowadzono je według znowelizowanych przepisów węgierskich, określających zasady wyboru Rappresentanza di Fiume ${ }^{6}$.

\section{Wloska Izba Deputowanych i zasady wyboru jej czlonków po 1918 r.}

Konstytucją istniejącego od 1861 r. Królestwa Włoch stał się Statut Albertyński, wydany w 1848 r. jako ustawa zasadnicza Królestwa Sardynii. Na podstawie przepisów Statutu władzę ustawodawczą sprawował dwuizbowy parlament, złożony z obieralnej Izby Deputowanych oraz Senatu, którego członków mianował monarcha. W drugim dziesięcioleciu XX w. przeprowadzono poważne zmiany prawa wyborczego, w wyniku których głosowanie stało się powszechne dla mężczyzn (1912 r.), a mandaty rozdzielano według systemu proporcjonalnego $(1919 \text { r.) })^{7}$.

Po tzw. reformie Giolittiego przeprowadzonej w 1912 r. wybory stały się niemal powszechne (choć jedynie dla mężczyzn). Czynne prawo wyborcze posiadali mężczyźni, którzy ukończyli 30 lat (będący obywatelami Włoch i posiadający prawa cywilne i polityczne), a młodsi, w wieku 21-30 lat, mogli głosować pod warunkiem spełnienia dodatkowych wymogów (dotyczących majątku, wykształcenia lub odbycia służby wojskowej). Dalsze upowszechnienie prawa głosu przyniosła reforma przeprowadzona w grudniu 1918 r. Dopuszczono wówczas do głosowania wszystkich mężczyzn, którzy ukończyli 21 lat, a także młodszych, którzy odbyli służbę wojskową. Głosować nie mogły kobiety oraz żołnierze w służbie czynnej ${ }^{8}$.

Bierne prawo wyborcze zostało określone w przepisach Statutu Albertyńskiego, zaś kolejne ordynacje wyborcze mogły jedynie uzupełnić wymogi wynikające z konstytucji (wprowadzając na przykład niepołączalność mandatu poselskiego

\footnotetext{
${ }^{6}$ Ibidem, s. 546.

${ }^{7}$ M. Rakowski: Prawo wyborcze do włoskiej Izby Deputowanych w latach 1861-1923. Warszawa 2004, s. 8-9.

${ }^{8}$ Ibidem, s. 52-110; zob. też: Legge 30 giugno 1912, n. 665, sulla riforma della legge elettorale politica. „Gazzetta ufficiale del Regno”, 5-6.07.1912, nr 159; Legge 30 giugno 1912, $n$. 666, contenente il nuovo testo unico della legge elettorale politica. „Gazzetta ufficiale del Regno", 6.07.1912, nr 159.
} 
z pewnymi funkcjami publicznymi lub przynależnością do stanu duchownego). Zgodnie z art. 40 i 64 ustawy zasadniczej do warunków objęcia mandatu należało: bycie poddanym króla Włoch, posiadanie w Królestwie pełni praw cywilnych i politycznych oraz ukończenie 30 lat, a także niezasiadanie w Senacie. Dopiero w 1912 r. wprowadzono procedurę rejestrowania kandydatów, co wiązało się z możliwością weryfikowania spełnienia warunków wybieralności przed dniem wyborów (wcześniej następowało to dopiero w Izbie Deputowanych, a wyborcy zapisywać mogli na kartach do głosowania dowolne nazwiska) ${ }^{9}$.

Do końca I wojny światowej obowiązywał we Włoszech większościowy system wyborczy w okręgach jednomandatowych ${ }^{10}$. Radykalna zmiana systemu wyborczego nastąpiła $\mathrm{w}$ wyniku nowelizacji ordynacji wyborczej przeprowadzonej w dniu 15 sierpnia 1919 r., a więc na zaledwie dwa miesiące przed uchwaleniem aktu określającego wybór deputowanego przez miasto Fiume. Przyjęto wówczas proporcjonalny system wyborczy w wersji d'Hondta $\mathrm{z}$ dopuszczeniem głosów preferencyjnych (wspierających niektórych kandydatów z popieranej listy) oraz tzw. panachage (możliwości oddawania głosów na kandydatów z innych list, co wpływało na ich pierwszeństwo do zdobycia mandatu) ${ }^{11}$.

\section{Zasady wyborów Rady Narodowej Fiume}

W październiku 1919 r. obowiązywały przepisy określające zasady wyboru Rady Narodowej Fiume. Pochodziły one jeszcze z lat panowania węgierskiego, a po powstaniu Rady poddano je tylko niewielkim zmianom.

Moc obowiązującą zachowały przepisy Statutu Wolnego Miasta Fiume i jego Dystryktu, zatwierdzonego przez węgierskiego Ministra Spraw Wewnętrznych 27 kwietnia 1872 r. ${ }^{12}$, w którym określono zasady ustroju corpus separatum. Organem przedstawicielskim miała być Rappresentanza di Fiume (§ 24), a władzę wykonawczą sprawował podesta, wraz z pozostającym pod jego nadzorem magistratem (Magistrato civico), z kierownikiem (dirigente) na czele (§ 108-109). Reprezentacja liczyła 56 członków -50 wybranych w mieście i 6 w pozostałej części dystryktu. Jej członków wyłaniano na sześcioletnią kadencję, przy czym

${ }^{9}$ M. Rakowski: Prawo..., s. $129-163$.

10 Jedynie w latach 1882 - 1891 odbywały się wybory większościowe w okręgach kilkumandatowych (wybierających od 3 do 5 posłów).

${ }^{11}$ M. Rakowski: Prawo..., s. 167-277; zob. też: Modificazioni alla legge elettorale politica (Legge 15 agosto 1919, n. 1401). „Gazzetta ufficiale del Regno”, 16.08.1919, nr 195; Approvazione del testo unico della legge elettorale politica (R. decreto 2 settembre 1919, $n$. 1495). „Gazzetta ufficiale del Regno”, 4.09.1919, nr 211.

12 Statuto della Libera Città di Fiume e del suo Distretto. Fiume 1908. 
co trzy lata miała być wybierana połowa przedstawicieli (§ 25). W Statucie przewidziano istnienie dwóch okręgów wyborczych (distretti) - pierwszy obejmował całe miasto, a w drugim głosować mieli mieszkańcy trzech podmiejskich sottocomuni (§33).

Zgodnie z $§ 28$ Statutu czynnym prawem wyborczym cieszyły się osoby umiejące czytać i pisać, które posiadały prawo głosu do parlamentu węgierskiego, a także kapitanowie i porucznicy żeglugi wielkiej; w $§ 29$ wskazano szereg przesłanek wyłączenia od udziału w głosowaniu. Uprawnieni do głosowania z urzędu podlegali wpisowi do rejestru wyborców (liste elettorali), sporządzanego przez magistrat odrębnie dla każdego z okręgów (§ 35). Szczegółowo opisano zasady wykładania rejestrów do publicznego wglądu oraz wnoszenia reklamacji dotyczących treści wpisu lub pominięcia w rejestrze (§ 36-38). Przed głosowaniem magistrat wydawał wyborcom stosowne zaświadczenia (carte di legitimazione) - $\S 38$ in fine.

Bierne prawo wyborcze - uregulowane w $\S 30$ - służyło „członkom komuny" (czyli mieszkańcom gminy Fiume), którzy posiadali prawo głosu, ukończyli 24 lata i przynajmniej od dwóch lat stale zamieszkiwali we Fiume. Również w zakresie prawa wybieralności przewidziano wyłączenia, które dotyczyły między innymi cudzoziemców, analfabetów, osób uzyskujących dochód na podstawie kontraktów władzami komunalnymi, a także zalegających ze spłatą zobowiązań dłużników gminy. Nie przewidziano procedury zgłaszania i rejestracji kandydatów, nie było więc podstaw do poprzedzającej głosowanie weryfikacji wypełnienia warunków wybieralności oraz sporządzenia kart do głosowania zawierających nazwiska kandydatów. Dopiero po wyborach Reprezentacja przeprowadzić miała badanie posiadania biernego prawa wyborczego przez jej nowych członków (§ 43).

W każdym z okręgów działała komisja wyborcza złożona z członka Reprezentacji oraz czterech wyborców wybranych przez Reprezentację (§ 39). Przybywający na głosowanie miał okazać otrzymane zaświadczenie, a do komisji powinien zgłosić się o godzinie w tym zaświadczeniu wskazanej (§ 40).

Na mocy przepisów Statutu wprowadzono większościowy system wyborczy w wielomandatowych okręgach, bez jakichkolwiek gwarancji reprezentacji mniejszości (których zastosowanie byłoby ze wszech miar celowe w wielonarodowym mieście ${ }^{13}$ ). Zgodnie z $\S 40$ wyborca oddawał głos na karcie (cedola), na której zapisywał nazwiska tylu kandydatów, ilu reprezentantów wybierano w danym okręgu $^{14}$. W tym samym $\S 40$ wskazano, że reprezentantami zostawali kandydaci, którzy otrzymali względną większość głosów, pod warunkiem że było to więcej

${ }_{13}$ Takie określenie zasad wyboru przedstawicieli prowadzić mogło do zmonopolizowania Reprezentacji przez mieszkańców pochodzenia włoskiego.

${ }^{14}$ Przewidziano przy tym odpowiednie zwiększenie liczby zapisywanych nazwisk, gdyż wybór części osób mógł okazać się nieskuteczny. Nie wyjaśniono za to, czy wskazanie mniejszej liczby nazwisk czyniło głos nieważnym (przypuszczam, że nie). 
niż 1/4 liczby wszystkich głosów oddanych w okręgu. W przypadku równej liczby głosów rozstrzygało losowanie. Wprowadzenie warunku w postaci uzyskania odpowiedniej części wszystkich oddanych głosów było o tyle zaskakujące, że prawodawca nie wskazał sposobu postępowania, gdyby wskutek niespełnienia tego warunku nie doszło do obsadzenia wszystkich mandatów.

Po ustaleniu wyników głosowania komisja sporządzała protokół i ogłaszała ustalone wyniki. Na podstawie otrzymanych z komisji protokołów reprezentujący rząd węgierski gubernator zwoływał posiedzenie Reprezentacji (§ 41). Szczególne rozwiązanie znajdujemy w § 44 Statutu. Był on konsekwencją zasady, że wyborcy na karcie do głosowania zapisywać mogli nazwiska dowolnie wybranych osób. Mogło się zatem zdarzyć, że wśród zwycięzców wyborów znajdzie się osoba, która o mandat nie zabiegała. Dlatego prawodawca zdecydował się wprowadzić obowiązek objęcia mandatu, a uchylenie się od jego przyjęcia było możliwe tylko w wyliczonych przypadkach (na przykład z powodu wieku bądź wcześniejszego zasiadania $w$ Reprezentacji). Nieuzasadniona odmowa przyjęcia wyboru skutkowała utratą czynnego i biernego prawa wyborczego.

We wrześniu 1919 r. dotyczące wyborów przepisy Statutu zostały dwukrotnie znowelizowane. Wydaną przez Komitet Wykonawczy Rady Narodowej ustawą z 6 września ${ }^{15}$ zmieniono przepisy odnoszące się do czynnego prawa wyborczego (§ 28). Prawo głosu przyznano wszystkim należącym do gminy (pertinenti al comune di Fiume), mężczyznom i kobietom, którzy ukończyli 20 lat lub wiek ten ukończą w roku wyborów (art. 1) ${ }^{16}$. Jednocześnie nieznacznie zmieniono treść § 29 (zamiast wyłączenia osób pozostających pod opieką, kuratelą lub władzą ojcowską przewidziano wyłączenie z powodu choroby umysłowej art. 2). Komitet Wykonawczy upoważniono do skrócenia niektórych terminów wskazanych w Statucie oraz zwiększenia liczby komisji wyborczych (art. 3).

Już następnego dnia wydany został dekret Komitetu Wykonawczego ${ }^{17}$, na mocy którego dokonano zapowiedzianego skrócenia niektórych terminów wskazanych w Statucie, co skutkowało przyspieszeniem sporządzania rejestrów wyborców (art. 1-3). Liczbę komisji wyborczych powiększono do dziesięciu ośmiu w mieście, dwóch poza miastem (art. 4).

${ }^{15}$ Legge 6 settembre 1919, n. 5710 concernente le elezioni della rappresentanza della libera città di Fiume e suo distretto. In: Ministero della Giustizia...: Legislazione... Vol. 1: Provvedimenti..., s. 82-83.

${ }^{16}$ Rozszerzenie praw wyborczych w zakresie prawa głosu przekładało się także na bierne prawo wyborcze.

17 Decreto 7 settembre 1919, n. 5732 circa le liste elettorali. In: Ministero della Giustizia...: Legislazione... Vol. 1: Provvedimenti..., s. 83-84. 


\section{Fiumeńska ordynacja wyborcza do parlamentu wloskiego}

Zasady wybierania posła do włoskiej Izby Deputowanych zostały określone w dekrecie z mocą ustawy, wydanym przez Komitet wykonawczy Rady Narodowej w dniu 14 października 1919 r. Zgodnie z jego art. 40 akt miał zostać przedstawiony Radzie Narodowej w celu ,przekształcenia w ustawę”. Nie udało się ustalić, czy dyspozycja ta została zrealizowana, nie ma jednak podstaw, by przypuszczać, że do przedstawienia nie doszło. Przepisy ordynacji miały wejść w życie z dniem publikacji aktu w Bolletino ufficiale, a za ich wykonanie mieli odpowiadać delegaci Rady Narodowej właściwi w sprawach wewnętrznych oraz sprawiedliwości (art. 39).

W art. 1 dekretu wskazano, że miasto i dystrykt Fiume miały tworzyć jeden okręg (dosłownie: kolegium) wybierający posła do parlamentu. Nie wskazano przy tym wyraźnie, że chodziło o parlament włoski, a dokładniej — o jego pochodzącą z wyborów Izbę Deputowanych.

Czynne prawo wyborcze zostało określone wyraźnie inaczej niż we włoskiej ordynacji z 1918 r. Zgodnie z art. 2 wyborcami byli: „obywatele włoscy, bez różnicy płci, którzy cieszą się prawami cywilnymi i politycznymi, posiadający przynależność do Comune di Fiume, którzy ukończyli 20. rok życia lub ukończą go podczas roku (dosł. „roku słonecznego” - l'anno solare), w którym zwołane będą komisje". W art. 3 wskazano przesłanki pozbawienia czynnego prawa wyborczego, co dotyczyło osób ubezwłasnowolnionych, upadłych, korzystających z publicznej dobroczynności, a także kobiet zawodowo trudniących się prostytucją. Krąg wyborów wyraźnie szerszy niż w ówczesnym włoskim prawie wyborczym. Zasadnicza różnica polegała na dopuszczeniu do wybierania kobiet, przy czym ich udział w wyborach miał we Fiume długą tradycję. Na niższym poziomie został ustalony cenzus wieku, za to nie przewidziano jego obniżenia dla osób, które odbyły służbę wojskową.

Warunkiem korzystania z czynnego prawa wyborczego było umieszczenie w spisie wyborców (la lista elettorale). Tak jak we Włoszech (po 1912 r.) obowiązywała zasada sporządzania rejestru wyborców z urzędu z dopuszczeniem dokonywania wpisów na wniosek. Spis uprawnionych miał być sporządzony przez władze samorządowe (il Municipio) i wyłożony co najmniej na trzy tygodnie przed datą wyborów (art. 5). Każdy obywatel był uprawniony do złożenia wniosku o wpisanie na listę jego samego lub osoby trzeciej, mógł również kwestionować prawidłowość umieszczenia osób w rejestrze (art. 6). Reklamacje takie miały zostać rozpatrzone w terminie trzech dni przez magistrat (il Magistrato civico), z prawem odwołania do specjalnej komisji złożonej z dziesięciu członków czynnych oraz pięciu zastępców członków. Komisja powoływana 
była przez Komitet Wykonawczy Rady Narodowej spośród wyborów, przewodniczył jej pierwszy prezes Sądu Apelacyjnego lub sędzia przezeń wyznaczony (art. 7 i 8). Ostateczny rejestr wyborców miał być wyłożony przynajmniej na sześć dni przed dniem głosowania (art. 9). Zgodnie z art. 10 podstawą udziału w głosowaniu miały być certyfikaty wystawione pod nadzorem Zarządu Miejskiego, doręczone wyborcom „w odpowiednim czasie".

$\mathrm{Na}$ terytorium Fiume nie obowiązywał Statut Albertyński, w którego art. 40 określono warunki objęcia mandatu deputowanego. Dlatego we fiumeńskiej ordynacji wyborczej konieczne było opisanie przesłanek korzystania z biernego prawa wyborczego. Zgodnie z art. 4 wybieralni byli mężczyźni, którzy posiadali czynne prawo wyborcze we Fiume i w Królestwie Włoch, ukończyli 25. rok życia, umieli pisać i czytać oraz nie zostali wykluczeni na podstawie jakiejkolwiek ustawy obowiązującej w Królestwie. Cenzus wieku był zatem aż o pięć lat niższy niż według przepisów włoskiej konstytucji. Jednocześnie sformułowano wymóg, by kandydat do Izby Deputowanych spełniał warunki stawiane mu przez prawo włoskie (także co do wymaganego wieku). Nietrudno zauważyć, że mężczyźni pomiędzy 26. a 30. rokiem życia nie spełniali wymagań określonych w Statucie Albertyńskim, ale osiągnęli próg wieku zapisany w ordynacji fiumeńskiej. Sprzeczność obu sformułowań jest oczywista. Intencją twórców ordynacji było najprawdopodobniej obniżenie cenzusu wieku do 25 lat, zatem odesłanie do przepisów obowiązujących w Królestwie nie obejmowało norm dotyczących wieku kandydata ${ }^{18}$. Jednocześnie trudno przyjąć, by mógł zasiadać w Izbie Deputowanych wybrany we Fiume deputowany, który nie ukończyłby jeszcze 30 lat, zatem nie spełniałby wymogów wyraźnie wskazanych w ustawie zasadniczej.

Zwraca też uwagę wyraźne zapisanie w ordynacji fiumeńskiej wymogu posługiwania się pismem (który we włoskim prawe wyborczym dotyczył jedynie wyborców, a nie kandydatów) oraz wyłączenie od kandydowania kobiet (którym przyznano jedynie prawo głosu).

Warunkiem korzystania z biernego prawa wyborczego było zgłoszenie kandydatury w sposób określony w art. 15. Pisemna deklaracja (dichiarazione), poparta podpisami przynajmniej stu obywateli umieszczonych w rejestrze wyborców, powinna trafić do burmistrza (sindaco) najpóźniej o godzinie $12 \mathrm{w}$ czwartek poprzedzający niedzielę będącą dniem wyborów. Deklaracja powinna zostać złożona osobiście przez przynajmniej czterech spośród podpisanych wyborców, którzy odpowiadali za autentyczność przedkładanych podpisów (art. 16).

Niełatwym zadaniem było określenie zasad zarządzania wyborów. $Z$ jednej strony oczywiste było, że powinny być one powiązane $\mathrm{z}$ wyborami odbywają-

${ }_{18}$ We Włoszech cenzus wieku dla biernego prawa wyborczego obniżono do 25 lat na mocy art. 88 faszystowskiej ustawy wyborczej z 18 listopada 1923 r., przy czym przepis ten był wyraźnie sprzeczny z art. 40 konstytucji, którego nie znowelizowano (co więcej — w Statucie Albertyńskim nie przewidziano możliwości zmiany jego treści). 
cymi się we Włoszech, z drugiej jednak istniała uzasadniona obawa, że władze w Rzymie nie zdecydują się na zarządzenie wyborów na spornym obszarze. Autorzy dekretu zdecydowali się na rozwiązanie wariantowe. W art. 11 zapisano, że „kolegium wyborcze zwoływane jest przez Króla”, dodano jednak, że dopóki będzie trwała okupacja wojskowa miasta, wybory zarządzane będą przez komendanta włoskich wojsk okupacyjnych. Przyjęte rozwiązanie było dość ryzykowne dla fiumeńskich Włochów, bowiem decyzję o przeprowadzeniu wyborów pozostawiono w rękach przedstawiciela Królestwa. Trudno przyjąć, by dowódca sił włoskich bez zgody rządu w Rzymie podjął tak ryzykowną politycznie decyzję.

Wybory miały się odbywać w dziesięciu sekcjach (sezioni), wyznaczonych dekretem sindaco (art. 13). Zgodnie z art. 14 głosowanie w sekcji miało być przeprowadzone przez komisję wyborczą (un ufficio elettorale) złożoną z przewodniczącego i wiceprzewodniczących (wyznaczonych przez pierwszego przewodniczącego Sądu Apelacyjnego, w miarę możliwości spośród sędziów) oraz czterech skrutatorów i sekretarza (powołanych przez Komitet Wykonawczy Rady Narodowej). Przy każdej komisji miało działać dwóch funkcjonariuszy wyznaczonych przez sindaco do sprawdzania tożsamości głosujących (art. 18 zd. 1). Komisja wyborcza miała być gwarantem prawidłowości przebiegu czynności wyborczych, a jej członkowie mieli się powstrzymać od jakiegokolwiek wpływania na głosowanie (art. 21).

W pracach komisji wyborczej mogli uczestniczyć mężowie zaufania kandydatów (fiduciari — nie więcej niż dwóch w każdej sekcji), wyznaczeni przez osoby zgłaszające kandydata (art. 17). Mężowie zaufania mogli w danej sekcji wyznaczyć osobę umocowaną do nadzorowania sprawdzania tożsamości wyborców (art. $18 \mathrm{zd}$. 2).

Głosowanie rozpoczynało się o godzinie 8 (art. 19). Trwało do godziny 17; jeśli jednak o tej godzinie byli obecni wyborcy, którzy nie oddali głosu, ulegało ono przedłużeniu, nie później niż do godziny 20 (art. 20). Głosowanie miało się odbywać publicznie, choć wstęp na salę miały tylko osoby, które okazały swój certyfikat umieszczenia w spisie wyborców (art. 22). Komisja wyborcza korzystała z ochrony prawnej, a jej przewodniczący miał zapewnić porządek w sali głosowania i mógł wezwać „siły publiczne” lub siły zbrojne w celu usunięcia lub aresztowania osoby utrudniającej prawidłowy przebieg głosowania (art. 23).

Wyborcom przybywającym na głosowanie odbierano certyfikaty, a ich nazwiska sekretarz komisji odnotowywał w protokole (art. 24). W dekrecie wskazano, że głosowanie odbywa się na kartach z białego papieru, które powinny zawierać nazwisko kandydata oraz - ewentualnie - jego tytuł akademicki, zawodowy lub szlachecki (art. 25). Z tak sformułowanego przepisu nie wynikało, czy wyborcy mieli przybyć z kartami do głosowania (wypisanymi własnoręcznie lub przygotowanymi przez sztab kandydata), czy też od członków komisji otrzymywali karty urzędowe. Przyjmujemy, że fiumeński prawodawca wybrał 
pierwsze rozwiązanie, gdyż w przepisach dekretu nie określono ani wzoru karty, ani obowiązku opatrzenia jej pieczęcią.

W art. 26 określono warunki ważności głosu. Głos był nieważny, jeśli karta została opatrzona jakimś szczególnym znakiem, nazwisko na karcie zostało unieważnione przez przekreślenie go lub w inny sposób, karta nie zawiera głosu na żadnego kandydata lub obok nazwiska kandydata zawiera inne nazwisko, na karcie został zastrzeżony warunek lub inne ograniczenie. Głos miał być też nieważny, gdyby wyborca posłużył się więcej niż jedną kartą (jeśli jednak było na nich nazwisko jednego tylko kandydata, głos mógł zostać uwzględniony).

Po zakończeniu głosowania komisje w sekcjach przeprowadzały liczenie głosów, a protokół z wynikami wywieszały w lokalu głosowania, przesyłając inny jego egzemplarz pierwszemu przewodniczącemu Sądu Apelacyjnego (art. 27). Dalsze czynności wykonywał Sąd Apelacyjny w składzie trzech sędziów, działający jako komisja centralna (ufficio centrale). Należało do niej zsumowanie głosów otrzymanych przez każdego z kandydatów, tymczasowe rozstrzygnięcie w przedmiocie wszelkich incydentów zaistniałych podczas czynności tej komisji, a także ustalenie zbiorczych wyników głosowania w okręgu (art. 28). Jednocześnie prawodawca wyraźnie pozbawił centralną komisję możliwości zajmowania się kwestią ważności głosów, skarg (reclami), protestów (proteste) oraz incydentów zaistniałych w sekcji głosowania. Nie miała też ona uprawnień do zmieniania wyników głosowania wskazanych w protokołach oraz do zajmowania się innymi sprawami, niż te, które zostały jej wyraźnie powierzone (art. 29) ${ }^{19}$.

Autorzy analizowanej ordynacji nie mieli swobody wyboru systemu wyborczego. Ponieważ zdecydowali się na przyjęcie jako zasady, że region Fiume wybiera tylko jednego posła do rzymskiego parlamentu, implikowało to wprowadzenie większościowego systemu wyborczego $\mathrm{w}$ jednomandatowych okręgach. Rozstrzygnięcia wymagało jedynie określenie warunków wyboru deputowanego (większością zwykłą, bezwzględną, z ewentualnymi dodatkowymi warunkami). Tryb wyboru posła określono $\mathrm{w}$ art. 31. Mandat zdobywał ten $\mathrm{z}$ kandydatów, którego liczba głosów była większa od 1/10 liczby wszystkich wyborów w kolegium oraz większa niż połowa liczby głosów oddanych przez wyborców. Po ogłoszeniu o dokonanym wyborze przewodniczący centralnej komisji niezwłocznie przesyłał odpowiednią informację sekretarzowi Izby Deputowanych oraz sindaco, do którego należało podanie jej do publicznej wiadomości (art. 32). Jeśli w pierwszym głosowaniu nie wybrano posła, przeprowadzano głosowanie balotażowe (ballotaggio), w którym mieli wziąć udział dwaj kandydaci, którzy otrzymali największą liczbę głosów. W przypadku równej liczby głosów do drugiej tury wyborów przechodził kandydat starszy wiekiem. Głosowanie balota-

19 Zasady sporządzania protokołów z czynności centralnej komisji określono w art. 36. Warto zwrócić uwagę, że jeden z egzemplarzy protokołu, wraz z załączonymi dokumentami, miał być przesyłką poleconą dostarczony sekretarzowi Izby Deputowanych (art. 36). 
żowe odbywało się w kolejną niedzielę. Na podstawie informacji przesłanej przez przewodniczącego centralnej komisji, syndyk informował o tym mieszkańców w odpowiednim obwieszczeniu (art. 33). W art. 34 znalazło się wskazanie, że do drugiej tury wyborów należało stosować przepisy o głosowaniu w pierwszej turze. Zgodnie z art. 35 zwycięzcą balotażu zostawał kandydat, który zdobył więcej głosów, a jeśli obaj kandydaci otrzymaliby tyle samo głosów — mandat zdobywał starszy wiekiem.

Fiumeńska ordynacja zawierała również przepisy karne. W art. 37 wskazano, że każdy funkcjonariusz wykonujący czynności związane $\mathrm{z}$ wyborami ${ }^{20}$, który przez działanie lub zaniechanie dopuściłby się pogwałcenia przepisów ordynacji (dosłownie: tej ustawy), podlegał odpowiedzialności karnej oraz dyscyplinarnej. Co ciekawe, prawodawca jako podstawową wskazał odpowiedzialność drugiego rodzaju, wspominając przy tym o „dodatkowych konsekwencjach przewidzianych w kodeksie karnym". Zauważyć przy tym należy, że w dacie uchwalenia ordynacji wyborczej we Fiume obowiązywał węgierski kodeks karny z 1878 r. $^{21}$, z niewielkimi modyfikacjami wprowadzonymi ustawą z 27 marca 1919 r. ${ }^{22}$.

$\mathrm{W}$ art. 38 przewidziano odpowiedzialność za usiłowanie uniemożliwienia lub zakłócenia przeprowadzenia wyborów lub ich prawidłowego przebiegu przez wywieranie bezprawnej presji na wyborców, wywoływanie zakłóceń w miejscu zebrania lub głosowania, nieprzestrzeganie poleceń władz powołanych do czynności wyborczych lub w jakikolwiek inny sposób. Sprawca podlegał karze pozbawienia wolności do sześciu miesięcy oraz grzywnie do wysokości 10000 koron; niezależnie od tego miał odpowiadać również na podstawie przepisów kodeksu karnego.

\section{Wybór deputowanego miasta Fiume i jego losy w Izbie Deputowanych}

Omawiana wyżej ordynacja znalazła praktyczne zastosowanie już 16 listopada 1919 r., bowiem w tym dniu we Włoszech odbywały się wybory parlamentarne. Władze rzymskie nie uwzględniły Fiume przy wyznaczaniu okręgów

\footnotetext{
${ }^{20} \mathrm{~W}$ przepisie wyliczono, jakie czynności i w jakim charakterze wykonywał sprawca.

${ }^{21}$ J. Ciągwa: Węgierski kodeks karny Károlya Csemegi. „Z Dziejów Prawa” 2005, cz. 5, s. $57-77$.

${ }^{22}$ Legge 27 marzo 1919, n. 2061 portante modificazioni alla legislazione ungarica in genere ed a quella penale in ispecie nel territorio giurisdizionale della cittá di Fiume nei riguardi del diritto di sovranitá. In: Ministero della Giustizia...: Legislazione... Vol. 1: Provvedimenti..., s. $59-61$.
} 
wyborczych, przeprowadzenie głosowania było zatem jednostronnym gestem samozwańczych władz miasta.

Zgłoszony został tylko jeden kandydat - Luigi Rizzo ${ }^{23}$ (ur. 1887 r.), okryty sławą dowódca okrętu w I wojnie światowej. Otrzymał 7409 głosów na 7434 głosujących, zatem głosowanie stało się plebiscytem za przynależnością do Włoch, przy czym wzięli z nim udział tylko zwolennicy aneksji. Wybór Rizza nie został uznany w Izbie Deputowanych — rząd Francesco Saverio Nittiego nie zamierzał w sprawie Fiume stosować polityki faktów dokonanych ${ }^{24}$.

Jak podaje Silvino Gigante, dla wykonania dyspozycji z art. 32 ordynacji wyborczej, w dniu 29 listopada 1919 r. sekretarz (cancelliere) Sądu Apelacyjnego Fiume Luigi Paulettig stawił się u wiceprzewodniczącego Izby Deputowanych Giulio Alessio, który odmówił przyjęcia protokołu z wyborów oraz pakietu z kartami wyborczymi. Paulettig - tym razem z notariuszem i dwoma świadkami - ponowił próbę doręczenia dokumentów u sekretarza Izby, również bez powodzenia. Dokumenty zostały zdeponowane u rzymskiego notariusza, a do włoskiego parlamentu wpłynęły już po aneksji Fiume ${ }^{25}$.

Członkowie władz Fiume zapewne jeszcze przed wyborami zdawali sobie sprawę, że dokonany w mieście wybór deputowanego nie zostanie uznany w Rzymie. Dlatego - dla wprowadzenia Rizzo do parlamentu - ubiegał się on również o mandat w kolegium Messyna. Przywoływany już Giurati podaje, że i w tym przypadku jego wybór został unieważniony, nie wyjaśnia jednak, na jakiej podstawie ${ }^{26}$.

\section{Uwagi końcowe}

Wybór przez mieszkańców Fiume posła do parlamentu włoskiego miał być potwierdzeniem woli przyłączenia miasta do Italii. Nieprzypadkowo głosowanie przeprowadzono w tym samym dniu (16 listopada 1919 r.), w którym do urn poszli mieszkańcy Królestwa. Posła z Fiume nie dopuszczono do Izby Deputowanych, ale podjęta akcja miała swoją symboliczną i propagandową wymowę, co zapewne było jej głównym celem.

${ }_{23}$ M. Gabriele: Rizzo, Luigi. In: Dizionario Biografico degli Italiani, 2016, Vol. 87, www. treccani.it/enciclopedia/luigi-rizoo_\%28Dizionario-Biografico\%29/ [dostęp: 8.12.2018].

${ }^{24}$ S. Gigante: Storia del Comune..., s. 224-225; G. Giuriati: Con D'Annunzio..., s. $62-64$.

${ }_{25}$ S. Gigante: Storia del Comune..., s. 225; zob. też: G. Giuriati: Con D’Annunzio..., s. $63-64$.

${ }^{26}$ S. Gigante: Storia del Comune..., s. 224. 
Ordynacja wyborcza z 14 października 1919 r. została uchwalona zaledwie miesiąc po przejęciu władzy przez d'Annuznio i na miesiąc przed dniem wyborów. Trudno zatem nie zgodzić się z Giovannim Giuriatim, że opracowano ją z „fiumeńską szybkością"27. Mimo tempa prac powstał akt dość obszerny, zawierający kompleksową regulację postępowania wyborczego, bez rzucających się w oczy luk i sprzeczności. Nie doszło przy tym ani do powielenia rozwiązań z obowiązującej wówczas ordynacji włoskiej, ani też nie powtórzono postanowień Statutu z 1872 r. odnoszących się do wyboru Reprezentacji Fiume. Nie znamy przyczyn, dla których autorzy aktu nie skorzystali z rozwiązania najprostszego, które polegałoby na zadeklarowaniu obowiązywania ordynacji włoskiej z koniecznymi modyfikacjami (wynikającymi z wyboru tylko jednego posła oraz innej struktury władz lokalnych wykonujących czynności związane ze sporządzaniem rejestru wyborców ${ }^{28}$ ).

Ordynacja z 14 października 1919 r. wyraźnie różniła się od rozwiązań włoskich. Najpoważniejsza odrębność polegała na dopuszczeniu kobiet do udziału w wyborach, choć jedynie w charakterze głosujących. Na nieco niższym poziomie określono cenzus wieku, za to nie przewidziano jego obniżenia dla osób, które odbyły służbę wojskową. Inaczej niż w Statucie Albertyńskim opisano przesłanki nabycia biernego prawa wyborczego (przy czym również nie skorzystano z możliwości odesłania do włoskiej konstytucji).

Wybór deputowanego miasta Fiume z oczywistych względów odbywał się według reguł wyborów w okręgu jednomandatowym, $\mathrm{z}$ ewentualną drugą turą głosowania. Natomiast wybory, które odbyły się w Królestwie w listopadzie 1919 r., były pierwszymi w dziejach Italii wyborami z zastosowaniem systemu proporcjonalnego, bez konieczności głosowania balotażowego. Okazuje się zatem, że badany akt to nie tylko szczególny przypadek ordynacji regulującej wyłanianie jednego tylko posła, ale określał on zasady jego wyboru w sposób wyraźnie odmienny niż wszystkich pozostałych członków Izby Deputowanych.

\section{Bibliografia}

\section{Źródla}

Approvazione del testo unico della legge elettorale politica ( $R$. decreto 2 settembre 1919, n. 1495). „Gazzetta ufficiale del Regno”, 4.09.1919, n. 211.

${ }^{27}$ G. Giuriati: Con D'Annunzio..., s. 63.

${ }^{28}$ Wystarczające mogłoby być wskazanie, że dany organ administracji Fiume wykonuje czynności przypisane do wskazanego organu włoskiego. 
Decreto 22 gennaio 1918, n. 407, concernente le norme per il funzionamento del Consiglio Nazionale Italiano di Fiume. In: Ministero della Giustizia e degli Affari di Culto. Comitato Tecnico per La Legislazione Relativa all'Unificazione del Diritto nelle Nuove Provicie. Legislazione di Fiume. Raccolta e coordinata da D. Barone, G.P. Gaetano. Vol. 1: Provvedimenti legislativi dei governi provvisori. Roma 1926.

Legge 30 giugno 1912, n. 665, sulla riforma della legge elettorale politica. „Gazzetta ufficiale del Regno", 5-6.07.1912, n. 159.

Legge 30 giugno 1912, n. 666, contenente il nuovo testo unico della legge elettorale politica. „Gazzetta ufficiale del Regno”, 6.07.1912, n. 159.

Legge 27 marzo 1919, n. 2061 portante modificazioni alla legislazione ungarica in genere ed a quella penale in ispecie nel territorio giurisdizionale della cittá di Fiume nei riguardi del diritto di sovranitá. In: Ministero della Giustizia e degli Affari di Culto. Comitato Tecnico per La Legislazione Relativa all'Unificazione del Diritto nelle Nuove Provicie: Legislazione di Fiume. Raccolta e coordinata da D. Barone, G.P. Gaetano. Vol. 1: Provvedimenti legislativi dei governi provvisori. Roma 1926.

Modificazioni alla legge elettorale politica (Legge 15 agosto 1919, n. 1401). „Gazzetta ufficiale del Regno", 16.08.1919, n. 195.

Legge 6 settembre 1919, n. 5710 concernente le elezioni della rappresentanza della libera città di Fiume e suo distretto. In: Ministero della Giustizia e degli Affari di Culto. Comitato Tecnico per La Legislazione Relativa all'Unificazione del Diritto nelle Nuove Provicie: Legislazione di Fiume. Raccolta e coordinata da D. Barone, G.P. Gaeta no. Vol. 1: Provvedimenti Legislativi dei Governi Provvisori. Roma 1926.

Decreto 7 settembre 1919, n. 5732 circa le liste elettorali. In: Ministero della Giustizia e degli Affari di Culto. Comitato Tecnico per La Legislazione Relativa all'Unificazione del Diritto nelle Nuove Provicie: Legislazione di Fiume. Raccolta e coordinata da D. Barone, G.P. Gaetano. Vol. 1: Provvedimenti legislativi dei governi provvisori. Roma 1926.

Droit et devoirs de l'Italie. [Roma 1919].

Giurati G.: Con D’Annunzio e Millo in difesa dell'Adriatico. Firenze 1954.

Statuto della Libera Città di Fiume e del suo Distretto. Fiume 1908.

\section{Opracowania}

Batowski H.: Rozpad Austro-Wegier 1914-1918. (Sprawy narodowościowe i działania dyplomatyczne). Kraków 1982.

Benedetti G.: La pace di Fiume. Dalla conferenza di Parigi al trattato di Roma. Bologna 1924.

Caviglia E.: Il conflitto di Fiume. [Milano] 1948.

Ciąg wa J.: Węgierski kodeks karny Károlya Csemegi. „Z Dziejów Prawa” 2005, cz. 5.

De Michelis E.: Guida a D'Annunzio. Torino 1988.

Depoli A.: Fiume. Una storia meravigliosa. Padova 1969.

Gigante S.: Storia del Comune di Fiume. Firenze 1928. 
Patafta D.: Promjene u nacionalnoj strukturi stanovništva grada Rijeke od 1918. do 1924. godine. „Časopis za suvremenu povijest” 2004, nr 2 (vol. 36).

Rakowski M.: Niepodległe miasto na pograniczu włosko-jugosłowiańskim - ustrój Fiume przed wydaniem Karty Kwarneru. W: Pogranicza w historii prawa i myśli polityczno-prawnej. Red. D. Szpoper, P. Dąbrowski. Gdańsk-Olsztyn 2017.

Rakowski M.: Prawo wyborcze do wtoskiej Izby Deputowanych w latach 1861-1923. Warszawa 2004.

Sierpowski S.: Faszyzm we Włoszech 1919-1926. Wrocław-Warszawa-KrakówGdańsk 1973.

\section{Źródla internetowe}

Gabriele M.: Rizzo, Luigi. In: Dizionario Biografico degli Italiani 2016, Vol. 87, www.treccani.it/enciclopedia/luigi-rizoo_\%28Dizionario-Biografico\%29/ [dostęp: 8.12.2018].

Maciej Rakowski

\section{Wahlordnung für einen Abgeordneten Abgeordnetenwahlen zum italienischen Parlament im Freistaat Fiume}

Schlüsselwörter: Wahlrecht, Geschichte von Fiume, Geschichte von Rijeka, Italiens Geschichte

Zusammenfassung: Von November 1918 bis Januar 1924 blieb die Stadt Fiume (Rijeka) praktisch gesehen das Hoheitsgebiet, um das sich Italien und das Königreich der Serben, Kroaten und Slowenen stritten. Die Stadt wurde von den Italienern regiert, aber Rom beschloss nicht, sie ohne Zustimmung der alliierten Mächte zu annektieren. Während der fünf Jahre der Unabhängigkeit gab es in Fiume verschiedene politische Systeme, und von September 1919 bis Ende 1920 übte der italienische Dichter Gabriele D'Annunzio die diktatorische Macht aus. Nachdem er die Macht ergriffen hatte, beschloss er, dass die Stadt einen Abgeordneten zum römischen Parlament wählt, um seinen Willen zu betonen, sie an Italien anzuschließen. Die Wahlregeln wurden im Dekret vom 14. Oktober 1919 festgelegt, dessen Bestimmungen sich von der damaligen italienischen Wahlordnung und den in der Stadt geltenden Regeln für die Wahlen zum Nationalrat deutlich unterschieden. Anders als in Italien durften Frauen wählen. Die Wahlen fanden am 16. November 1919 statt, um das Abgeordnetenmandat bewarb sich nur ein Kandidat, Luigi Rizzo, dessen Wahl durch die italienischen Behörden nicht anerkannt wurde. 
Maciej Rakowski

\section{Electoral law for one deputy \\ Election of a member of the Italian Parliament in the Free State of Fiume}

Keywords: electoral law, history of Fiume, history of Rijeka, history of Italy

Summary: From November 1918 to January 1924, the town of Fiume (Rijeka) was in fact the sovereign territory over which Italy and the Kingdom of SHS disputed. The city was ruled by the Italians, but Rome did not decide to annex it without the consent of the allied powers. During the five years of independence there were various forms of political system in Fiume, and from September 1919 until the end of 1920 dictatorial power was held by the Italian poet Gabriele D'Annunzio. After he had taken power, he decided that the city would elect a member of the Roman parliament to emphasise the will to join Italy. The rules for election were laid down in the Decree of 14 October 1919, the provisions of which were clearly different from the Italian electoral law of that time and also from the city's rules for electing the National Council. Unlike in Italy, women were allowed to vote. The elections were held on 16 November 1919, and only one candidate, Luigi Rizzo, whose election was not recognised by the Italian authorities, stood for a mandate. 
